NOTICE: this is the author's version of a work that was accepted for publication in Journal of Supercritical Fluids. Changes resulting from the publishing process, such as peer review, editing, corrections, structural formatting, and other quality control mechanisms may not be reflected in this document. Changes may have been made to this work since it was submitted for publication. A definitive version was subsequently published in Journal of Supercritical Fluids, 62 (1), DOI 10.1016/j.supflu.2011.11.002 


\section{Accepted Manuscript}

Title: A fast method to equilibrate carbon dioxide with brine at high pressure and elevated temperature including solubility measurements

Authors: R.M. El-Maghraby, C.H. Pentland, S. Iglauer, M.J. Blunt

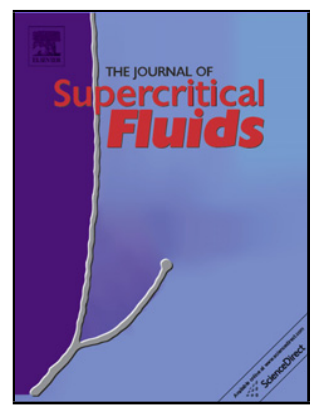

PII: S0896-8446(11)00472-4

DOI: doi:10.1016/j.supflu.2011.11.002

Reference: SUPFLU 2329

To appear in: J. of Supercritical Fluids

Received date:

28-5-2011

Revised date: 13-10-2011

Accepted date: 4-11-2011

Please cite this article as: R.M. El-Maghraby, C.H. Pentland, S. Iglauer, M.J. Blunt, A fast method to equilibrate carbon dioxide with brine at high pressure and elevated temperature including solubility measurements, The Journal of Supercritical Fluids (2010), doi:10.1016/j.supflu.2011.11.002

This is a PDF file of an unedited manuscript that has been accepted for publication. As a service to our customers we are providing this early version of the manuscript. The manuscript will undergo copyediting, typesetting, and review of the resulting proof before it is published in its final form. Please note that during the production process errors may be discovered which could affect the content, and all legal disclaimers that apply to the journal pertain. 


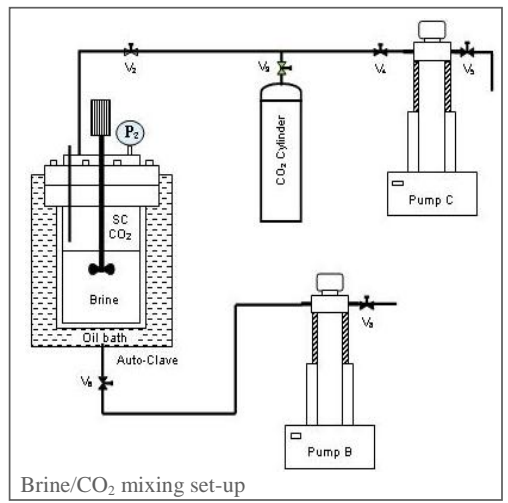

A fast method to equilibrate carbon dioxide with brine at high pressure and elevated temperature including solubility measurements

R. M. El-Maghraby ${ }^{1^{\star}}$, C.H. Pentland ${ }^{1,2}$, S. Iglauer ${ }^{1,3}$, M.J. Blunt $^{1}$

${ }^{1}$ Department of Earth Science and Engineering, Imperial College London SW7 2AZ, United Kingdom

${ }^{2}$ Current address Shell Global Solutions International

${ }^{3}$ Current address Curtin University, Department of Petroleum Engineering, 26 Dick Perry Avenue, 6151 Perth, Australia 
- We introduce a fast and easy methodology to equilibrate $\mathrm{CO}_{2}$ and brine in the liter range.

- Equilibration was reached in 60 minutes.

- This is an important step for $\mathrm{CO}_{2}$ storage studies and experiments.

- Solubility of $\mathrm{CO}_{2}$ in brine was measured using isothermal depressurization method.

- Comparing our solubility data with the literature shows its consistence. 


\title{
A fast method to equilibrate carbon dioxide with brine at high pressure and elevated temperature including solubility measurements
}

\author{
R. M. El-Maghraby ${ }^{1 *}$, C.H. Pentland ${ }^{1,2}$, S. Iglauer ${ }^{1,3}$, M.J. Blunt ${ }^{1}$ \\ ${ }^{1}$ Department of Earth Science and Engineering, Imperial College London SW7 2AZ, United \\ Kingdom \\ ${ }^{2}$ Current address Shell Global Solutions International \\ ${ }^{3}$ Current address Curtin University, Department of Petroleum Engineering, 26 Dick Perry \\ Avenue, 6151 Perth, Australia
}

${ }^{*}$ Corresponding author
e-mail: r.el-maghraby09@imperial.ac.uk

\begin{abstract}
:
We introduce a fast, easy and reliable methodology, using a stirred reactor, to equilibrate carbon dioxide with brine and measure the solubility of carbon dioxide in the aqueous phase at high pressure $(9 \mathrm{MPa})$ and elevated temperature $\left(33,50\right.$ and $\left.70^{\circ} \mathrm{C}\right)$ conditions at the litre scale. The solubility of carbon dioxide in brine was measured using an isothermal depressurization method and compared with data in the literature. This methodology can be used in petroleum engineering, carbon storage and chemical engineering applications.
\end{abstract}

Keywords: Equilibration of Brine $/ \mathrm{CO}_{2}$, Solubility of $\mathrm{CO}_{2}, \mathrm{CO}_{2}$ Storage, supercritical $\mathrm{CO}_{2}$, dissolution trapping.

\section{Introduction}

Long term storage of carbon dioxide $\left(\mathrm{CO}_{2}\right)$ in deep saline aquifers has been proposed to mitigate global warming [1]. Saline aquifers are abundant and geographically widespread with huge storage capacities [2-4]. The $\mathrm{CO}_{2}$ will likely be stored as a supercritical (sc) phase at depths of $800 \mathrm{~m}$ or more [2], which maximizes the stored mass of $\mathrm{CO}_{2}$.

When $\mathrm{CO}_{2}$ is injected into geological formations there are a number of trapping mechanisms which prevent its migration and subsequent escape to the atmosphere. These are: stratigraphic and structural trapping, geochemical trapping, solubility trapping, and capillary trapping [5]. These mechanisms are the subject of active research, and preparing an equilibrated mixture of carbon dioxide and brine is an important step for many of these experiments (see, for instance, [6-8]).

We present here a methodology with which $\mathrm{CO}_{2}$ can be rapidly equilibrated with brine at the litre-scale at high pressure and elevated temperature conditions representative of geological storage formations. This method could also be used to equilibrate other fluids if their viscosities are not too high, e.g. oils can be mixed with $\mathrm{CO}_{2}$ for petroleum engineering studies or $\mathrm{CO}_{2}$ can be mixed with other solvents (e.g. acetone, dichloromethane, diethyl ether, monoethanolamine, etc.) for chemical engineering applications.

In addition, the equilibrium solubility of $\mathrm{CO}_{2}$ in brine was measured with an accurate isothermal depressurization method. The results were consistent with literature data. Solubility data is crucial for assessing not only the effectiveness of solubility trapping but the equilibration methodology outlined is a crucial step in capillary trapping experiments which rely on immiscible phase displacements [6,9]. 


\section{Experimental Equipment and Conditions}

\subsection{Experimental Apparatus}

An equilibration reactor $(1200 \mathrm{~mL}$ C276 autoclave with gas entrainment stirrer - Parr Instruments Co., IL, USA) was used to establish equilibrium between the $\mathrm{CO}_{2}$ and brine phases. High precision syringe pumps (Teledyne ISCO 1000D, Lincoln, NE, USA) maintained pressures with high accuracy. The brine composition we used was $5 \mathrm{wt} \% \mathrm{NaCl}$ and $1 \mathrm{wt} \%$ $\mathrm{KCl}$ in deionized water. Figure 1 shows the experimental apparatus.

\subsection{Experimental Procedure}

\subsubsection{Rapid establishment of $\mathrm{CO}_{2} /$ brine equilibrium}

Three steps were developed to prepare brine saturated with $\mathrm{CO}_{2}$ and $\mathrm{CO}_{2}$ saturated with water vapour. During the first step $\mathrm{scCO}_{2}$ was prepared in a syringe pump $\mathrm{C}$, and a water heating jacket was used to heat the pump to the desired temperature $\left(33^{\circ} \mathrm{C}, 50^{\circ} \mathrm{C}\right.$ or $\left.70^{\circ} \mathrm{C}\right)$. Pump C and all tubing were vacuumed for 20 min, then high pressure gaseous $\mathrm{CO}_{2}(5 \mathrm{MPa}$ at $15^{\circ} \mathrm{C}$ ) was transferred to pump $\mathrm{C}$ from a $\mathrm{CO}_{2}$ cylinder by operating pump $\mathrm{C}$ in constant refill mode (the pump is driven by a stainless steel piston which was initially set to $0 \mathrm{ml}$ volume which is driven back to full capacity, i.e. $1015 \mathrm{ml}$ ). When pump $\mathrm{C}$ was completely filled with $\mathrm{CO}_{2}$ gas at the gas cylinder pressure, it was then pressurized to experimental pressure $(9 \mathrm{MPa})$; at these thermophysical conditions $\mathrm{ScCO}_{2}$ was generated.

During the second step, the reactor was heated to experimental conditions in an oil bath, then vacuumed and filled with de-aerated brine using a high precision syringe pump $\mathrm{B}$. The reactor was then pressurized up to our experimental condition using pump $\mathrm{B}$. The reactor is connected to the $\mathrm{scCO}_{2}$ pump C operating at the same pressure, then $500 \mathrm{ml}$ from the brine volume in the reactor were displaced by $\mathrm{scCO}_{2}$ from pump $\mathrm{C}$ (pump was set to constant pressure mode) and withdrawing brine with pump B (pump was set to constant refill flow rate mode). The reactor is then isolated from pump $B$.

In the third step $\mathrm{CO}_{2}$ and brine were brought to equilibrium inside the reactor by stirring with a stirrer at $200 \mathrm{rpm}$. The stirrer is a mixing shaft attached to a magnetic motor and has a gas entrapment design. It essentially pushes the lighter phase $\left(\mathrm{scCO}_{2}\right)$ into the bottom phase (brine) and generates a large surface area between the fluids by splitting the $\mathrm{CO}_{2}$ into many small bubbles. This maximization of the contact surface and turbulent flow assured rapid equilibration.

The pressure was maintained constant during the dissolution process with pump $C$ set to constant pressure mode. The pressure in the reactor was monitored using a pressure transducer (Rosemount 3051S pressure transmitter, Rosemount, USA) and pressure readings were logged on a computer. In addition the volume and pressure of pump $\mathrm{C}$ were logged to monitor $\mathrm{ScCO}_{2}$ volume balances.

Additional $\mathrm{CO}_{2}$ was pumped into the vessel during the equilibration process because the $\mathrm{CO}_{2}$ dissolved reducing the pressure. Equilibrium is reached if no more $\mathrm{CO}_{2}$ is pumped into the reactor and no change in pump $\mathrm{C}$ volume is detected. Equilibration was completed in 60 minutes; however for subsequent experiments [6-8] the system was left overnight to stabilize.

\subsection{Isothermal depressurization}

The solubility of $\mathrm{CO}_{2}$ in brine was measured in two steps by using the isothermal depressurization method.

In step 1 pump B was cleaned and vacuumed, then filled with de-aerated brine. The brine was pressurized to $9 \mathrm{MPa}$ and the brine volume $\left(V_{B 1}\right)$ was noted. The pressure was reduced gradually to atmospheric pressure. The volume $\left(V_{B 2}\right)$ in pump B was recorded after depressurization to atmospheric pressure. 
In step 2 pump B was emptied and vacuumed for 20 minutes, then a volume of $\mathrm{CO}_{2}$ saturated brine $\left(V_{M 1}\right)$ - (same volume as for the pressurized de-aerated brine $\left(V_{B 1}\right)$ (equation 1)) - was transferred from the reactor to pump $B$ by operating pump $C$ in constant pressure mode and allowing $\mathrm{CO}_{2}$ to displace some of the brine to pump B operating in constant refill mode.

$$
V_{M 1}=V_{B 1}
$$

This was conducted at constant pressure and temperature to prevent $\mathrm{CO}_{2}$ separating out of solution during the transfer process. After the required amount of $\mathrm{CO}_{2}$ saturated brine was transferred, pump B was isolated. Then the $\mathrm{CO}_{2}$-saturated brine mixture in pump $\mathrm{B}$ was expanded at constant temperature $\left(33^{\circ} \mathrm{C}, 50^{\circ} \mathrm{C}\right.$ or $\left.70^{\circ} \mathrm{C}\right)$ by reducing the applied pressure gradually. Starting with an operating pressure of $9 \mathrm{MPa}$, the pressure was reduced gradually until atmospheric pressure was reached. The volume $\left(V_{M 2}\right)$ in pump B was noted.

Dead volumes in the system were measured carefully and taken into account for volume balance calculations.

The isothermal expansion method is based on the concept that for a given volume of brine saturated with $\mathrm{CO}_{2}$, the $\mathrm{CO}_{2}$ is released if the pressure is reduced isothermally. If the volume of $\mathrm{CO}_{2}$ saturated brine is known before depressurization $\left(V_{M_{1}}\right)$ and the total brine volume is known after depressurization $\left(V_{M 2}\right)$, then the amount of $\mathrm{CO}_{2}$ that separated out of solution $\left(V_{\mathrm{CO}_{2}}\right)$ can be calculated by subtracting the two volumes (equation 2). We can then calculate the solubility of $\mathrm{CO}_{2}$ in brine at this condition.

$$
\text { Volume of } \mathrm{CO}_{2} \text { dissolved in the brine }\left(V_{\mathrm{CO} 2}\right)=V_{M 2}-V_{M 1}
$$

But to measure the solubility we have to consider two points to get an accurate measurement of solubility by using the isothermal depressurization method. First as the pressure is reduced, water vapor co-exists with $\mathrm{CO}_{2}$ gas above the liquid phase. Second the brine volume will change with pressure reduction due to compressibility. Equation 2 is therefore modified:

$$
V_{C O 2}+\Delta V_{B}+V_{W V}=V_{M 2}-V_{M 1}
$$

where $V_{W V}$ is the volume of water vapour above the liquid phase and $\Delta V_{B}$ is the change in brine volume with pressure due to compressibility.

So, step 1 was introduced to account for the compressibility of the brine and the amount of water vapour that will form on top of the liquid when the pressure is reduced. By isothermal depressurization of de-aerated brine we can know $V_{B 1}$ and $V_{B 2}$ and from equation 4 we can compute the sum of $\Delta V_{B}$ and $V_{W V}$

$$
\Delta V_{B}+V_{W V}=V_{B 2}-V_{B 1}
$$

Two assumptions were made. The first was assuming that the effect of $\mathrm{CO}_{2}$ presence on top of the liquid phase in step 2 on the amount of water vapour is negligible. Secondly we assumed that the $\mathrm{CO}_{2}$ present in the brine will not change its compressibility. Substituting equation 4 into equation 3 results in

$$
V_{C O 2}+V_{B 2}-V_{B 1}=V_{M 2}-V_{M 1}
$$

Rearranging equation 5 we get the actual amount of $\mathrm{CO}_{2}$ dissolved in the brine at the given operating conditions,

$$
V_{C O 2}=V_{B 1}-V_{B 2}+V_{M 2}-V_{M 1}
$$

Knowing the volume of $\mathrm{CO}_{2}$ dissolved in the brine we can calculate the number of moles of $\mathrm{CO}_{2}$ using the Peng-Robinson equation of state [10]. The density of brine was obtained from the literature [11]. At atmospheric pressure there is still some $\mathrm{CO}_{2}$ dissolved in the brine; this

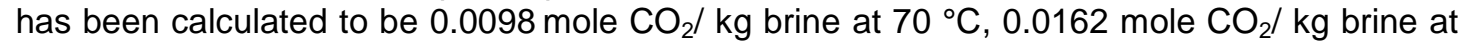


$50{ }^{\circ} \mathrm{C}$, and 0.0239 mole $\mathrm{CO}_{2} / \mathrm{kg}$ brine at $33^{\circ} \mathrm{C}$ based on literature models $[12,13]$ and was added to the total obtained solubility.

\section{Results and Discussion}

We tested the reactor for three thermophysical conditions $\left(9 \mathrm{MPa} / 33^{\circ} \mathrm{C}, 9 \mathrm{MPa} / 50^{\circ} \mathrm{C}\right.$ and 9 $\left.\mathrm{MPa} / 70^{\circ} \mathrm{C}\right)$ and measured $\mathrm{CO}_{2}$ solubilities in brine for a range of pressures $(9 \mathrm{MPa}, 7.58 \mathrm{MPa}$, $3.44 \mathrm{MPa}$ and $0.34 \mathrm{MPa})$ at three temperatures $\left(33^{\circ} \mathrm{C}, 50^{\circ} \mathrm{C}\right.$ and $\left.70^{\circ} \mathrm{C}\right)$. Our results are displayed in Table 1.

A similar solubility measurement has been described in the literature [8], although the way we account for water vapor is different. In [14] the separated $\mathrm{CO}_{2}$ gas from the equilibration mixture was bubbled through concentrated sulfuric acid solution to condense the water vapor. In $[15,16]$ water vapor in the gas phase was not considered.

$\mathrm{CO}_{2}$ solubility in brine at $70^{\circ} \mathrm{C}$ and $9 \mathrm{MPa}$ was measured three times to check experimental reproducibility $(0.842 \pm 0.0138)$ mole $\mathrm{CO}_{2} / \mathrm{kg}$ brine). The low standard deviation $(\approx 1.6 \%)$ demonstrates that the isothermal depressurization method is highly reproducible.

Our results are consistent with solubility data available in the literature (Table 2, Figures 2 and 3) [12, 14-27]. Only one brine of the same composition has been studied in the literature [22]; other data for similar brine compositions and operating conditions are also listed. It is interesting to note that a solution containing $\mathrm{KCl}$ will dissolve more $\mathrm{CO}_{2}$ than a solution containing an equal concentration (wt.\%) $\mathrm{NaCl}$ [16]; so $6 \mathrm{wt} . \% \mathrm{NaCl}$ solution will dissolve less $\mathrm{CO}_{2}$ than a $5 \mathrm{wt} \% \mathrm{NaCl} / 1 \mathrm{wt} . \% \mathrm{KCl}$ solution. In general at constant pressure and temperature the solubility decreases with increase in salinity (Figure 3).

\section{Conclusions}

A methodology to equilibrate brine with $\mathrm{CO}_{2}$ at the litre-scale was presented. In two easy and fast steps we rapidly equilibrated supercritical $\mathrm{CO}_{2}$ and brine at high pressure and elevated temperature. This method can be applied to a wide range of temperatures and pressures. We focus here on equilibrating brine and $\mathrm{scCO}_{2}$ as this is most relevant for carbon storage studies $[6,9,28]$. However, we suggest that different fluids can also be saturated with $\mathrm{CO}_{2}$ by using this method, e.g. in chemical engineering applications. Volumes in the liter range can be equilibrated in approximately one hour which is fast turn over compared with other mixing methods proposed.

The solubility of $\mathrm{CO}_{2}$ in brine was measured by using the isothermal expansion method. This method has proven to be accurate and fast when compared to the available methods and data in the literature (Figures 2 and 3 ).

\section{Acknowledgments}

We would acknowledge support from the Qatar Carbonates and Carbon Storage Research Centre funded jointly by Qatar Petroleum, Shell and the Qatar Science \& Technology Park.

\section{References}

[1] Intergovernmental Panel on Climate Change (IPCC), IPCC Special Report on Carbon Dioxide Capture and Storage. Prepared by Working Group III of the Intergovernmental Panel on Climate Change, Cambridge University Press, 2005.

[2] A. Firoozabadi, P. Cheng, Prospects for subsurface $\mathrm{CO}_{2}$ sequestration, $\mathrm{AlChE}$ Journal, 56 (2010), pp. 1398-1405.

[3] A. Kopp, H. Class, R. Helmig, Investigations on $\mathrm{CO}_{2}$ storage capacity in saline aquifers Part 1. Dimensional analysis of flow processes and reservoir characteristics, International Journal of Greenhouse Gas Control, 3 (2009), pp. 263-276. 
[4] S. Bachu, Sequestration of $\mathrm{CO}_{2}$ in geological media: criteria and approach for site selection in response to climate change, Energy Conversion and Management, $\mathbf{4 1}$ (2000), pp. 953-970.

[5] S. E. Gasda, J. M. Nordbottenb, M. A. Celia, The impact of local-scale processes on large-scale $\mathrm{CO}_{2}$ migration and immobilization, Energy Procedia, 4 (2011), pp. 38963903.

[6] C. H. Pentland, R. El-Maghraby, S. Iglauer, M. J. Blunt, Measurements of the capillary trapping of supercritical carbon dioxide in Berea sandstone, Geophysical Research Letters, 38 (2011), L06401.

[7] J. C. Perrin, M. Krause, C. W. Kuo, L. Milijkovic, S. M. Benson, Core-Scale experimental study of relative permeability properties of $\mathrm{CO}_{2}$ and brine in reservoir rocks, Energy Procedia, 1 (2009), pp. 3515-3522.

[8] T. Suekane, T. Nobuso, S. Hirai, M. Kiyota, Geological storage of carbon dioxide by residual gas and solubility trapping, International Journal of Greenhouse Gas Control, 2 (2008), pp. 58-64.

[9] C. H. Pentland, S. Iglauer, R. El-Maghraby, Y. Tsuchiya, H. Okabe, M. J. Blunt, Measurement of Carbon Dioxide Capillary Trapping in Core Analysis, Proceedings of SPE $2^{\text {nd }}$ International Conference on $\mathrm{CO}_{2}$ Capture, Storage, and Utilization; SPE 138476, New Orleans, Louisiana, USA, 2010.

[10] McCain, W.D., The properties of petroleum fluids, Tulsa: Penn Well Corporation, 1990.

[11] S. Mao, Z. Duan, The $P, V, T, x$ properties of binary aqueous chloride solutions up to $\mathrm{T}=573 \mathrm{~K}$ and $100 \mathrm{MPa}$, The Journal of Chemical Thermodynamics, 40 (2008), pp. 1046-1063.

[12] Z. Duan, R. Sun, An improved model calculating $\mathrm{CO}_{2}$ solubility in pure water and aqueous $\mathrm{NaCl}$ solutions from 273 to $533 \mathrm{~K}$ and from 0 to $2000 \mathrm{bar}$, Chemical Geology, 193 (2003), pp. 257-271.

[13] Z. H. Duan, R. Sun, C. Zhu, I. M. Chou, An improved model for the calculation of $\mathrm{CO}_{2}$ solubility in aqueous solutions containing $\mathrm{Na}^{+}, \mathrm{K}^{+}, \mathrm{Ca}^{2+}, \mathrm{Mg}^{2+}, \mathrm{Cl}^{-}$, and $\mathrm{SO}_{4}^{2-}$, Marine Chemistry, 98 (2006), pp. 131-139.

[14] J. A. Nighswander, N. Kalogerakis, A. K. Mehrotra, Solubilities of carbon dioxide in water and 1 wt. $\% \mathrm{NaCl}$ solution at pressures up to $10 \mathrm{MPa}$ and temperatures from 80 to $200^{\circ} \mathrm{C}$, J. Chemical and Engineering Data, 34 (1989), pp. 355-360.

[15] Z. Li, M. Dong, S. Li, L. Dai, Densities and solubilities for binary systems of carbon dioxide + water and carbon dioxide + brine at $59^{\circ} \mathrm{C}$ and pressures to $29 \mathrm{MPa}$, J. Chemical and Engineering Data, 49 (2004), pp. 1026-1031.

[16] Y. Liua, M. Houa, G. Yanga, B. Han, Solubility of $\mathrm{CO}_{2}$ in aqueous solutions of $\mathrm{NaCl}$, $\mathrm{KCl}, \mathrm{CaCl}_{2}$ and their mixed salts at different temperatures and pressures, Journal of Supercritical Fluids, 56 (2011), pp. 125-129.

[17] H. S. Kiepe, K. Fischer, J. Gmehling, Experimental determination and prediction of gas solubility data for $\mathrm{CO}_{2}+\mathrm{H}_{2} \mathrm{O}$ mixtures containing $\mathrm{NaCl}$ or $\mathrm{KCl}$ at temperatures between 313 and $393 \mathrm{~K}$ and pressures up to $10 \mathrm{MPa}$, Industrial \& Engineering Chemistry Research, 41 (2002), pp. 4393-4398. 
[18] S. Bando, F. Takemura, M. Nishio, E. Hihara, M. Akai, Solubility of $\mathrm{CO}_{2}$ in aqueous solutions of $\mathrm{NaCl}$ at (30 to 60) ${ }^{\circ} \mathrm{C}$ and (10 to 20) MPa, J. Chemical and Engineering Data, 48 (2003), pp. 576-579.

[19] A. N. Sabirzyanov, R. A. Shagiakhmetov, G. R. Gabitov, A. A. Tarzimanov, F. M. Gumerov, Water solubility of carbon dioxide under supercritical and subcritical conditions, Theoretical Foundations of Chemical Engineering, 37 (2003), pp. 51-53.

[20] D. Koschel, J. Y. Coxam, L. Rodier, V. Majer, Enthalpy and solubility data of $\mathrm{CO}_{2}$ in water and $\mathrm{NaCl}(\mathrm{aq})$ at conditions of interest for geological sequestration, Fluid Phase Equilibria, 247 (2006), pp. 107-120.

[21] W. S. Dodds, L. F. Stutzman, B. J. Sollami, Carbon dioxide solubility in water, Industrial and Engineering Chemistry, 1 (1956).

[22] M. Trusler, D. Vega-Maza, Solubility of $\mathrm{CO}_{2}$ in aqueous solutions of either $\mathrm{NaCl}$ and $\mathrm{KCl}$ or $\mathrm{MgCl}_{2}$ and densities of the $\mathrm{CO}_{2}$-saturated solutions at temperatures of (308 to 423) $\mathrm{K}$ and at pressures up to $40 \mathrm{MPa}$, to be published.

[23] N. Akinfieva, L. Diamond, Thermodynamic model of aqueous $\mathrm{CO}_{2}-\mathrm{H}_{2} \mathrm{O}-\mathrm{NaCl}$ solutions from -22 to $100^{\circ} \mathrm{C}$ and from 0.1 to $100 \mathrm{MPa}$, Fluid Phase Equilibria, 295 (2010), pp. 104-124.

[24] N. A. Darwish, N. Hilal, A simple model for the prediction of $\mathrm{CO}_{2}$ solubility in $\mathrm{H}_{2} \mathrm{O}-$ $\mathrm{NaCl}$ system at geological sequestration conditions, Desalination, 260 (2010), pp. 114-118.

[25] N. Spycher, K. Pruess, A Phase-Partitioning Model for $\mathrm{CO}_{2}$-Brine Mixtures at Elevated Temperatures and Pressures: Application to $\mathrm{CO}_{2}$-Enhanced Geothermal Systems, Transport in Porous Media, 82 (2010), pp. 173-196.

[26] X. Ji, S. P. Tan, H. Adidharma, M. Radosz, SAFT1-RPM Approximation Extended to Phase Equilibria and Densities of $\mathrm{CO}_{2}-\mathrm{H}_{2} \mathrm{O}$ and $\mathrm{CO}_{2}-\mathrm{H}_{2} \mathrm{O}-\mathrm{NaCl}$ systems, Industrial \& Engineering Chemistry Research, 44 (2005), pp. 8419-8427.

[27] N. Spycher, K. Pruess, $\mathrm{CO}_{2}-\mathrm{H}_{2} \mathrm{O}$ Mixtures in the Geological Sequestration of $\mathrm{CO}_{2}$. II. Partitioning in Chloride brines at $12-100^{\circ} \mathrm{C}$ and up to 600 bar, Geochimica Acta, 69 (2005), pp. 3309-3320.

[28] C. H. Pentland, R. El-Maghraby, A. Georgiadis, S. Iglauer, M. J. Blunt, Immiscible Displacements and Capillary Trapping in $\mathrm{CO}_{2}$ Storage, Proceedings of the Greenhouse Gas Control Technology Conference 2010, Amsterdam, The Netherlands, 2010. 


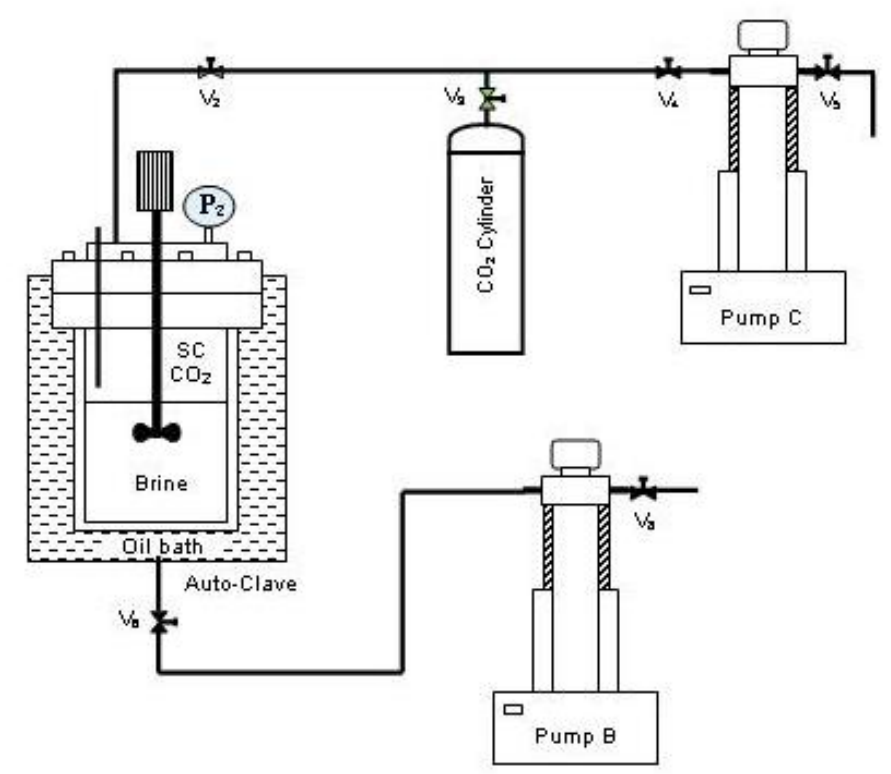

Figure 1: Experimental apparatus for brine- $\mathrm{CO}_{2}$ equilibrium.

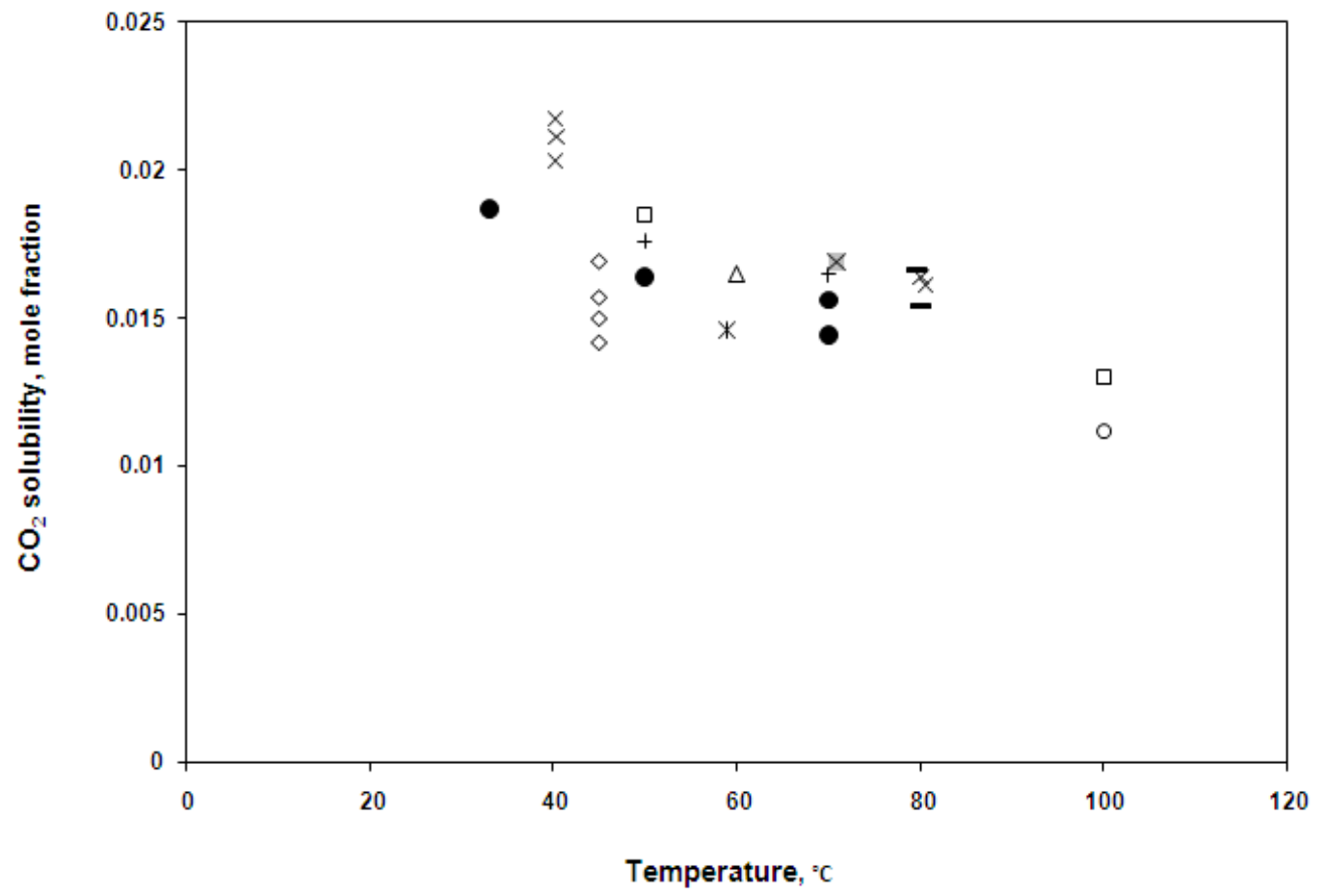

Figure 2: Solubility data for $\mathrm{CO}_{2}$ in brine with different salinities at CCS pressures (between 8.4-10.5 MPa) versus temperature - solid symbols are our measurements and open symbols are literature data;(-)

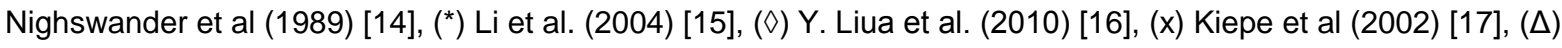
Bando et al. (2003) [18], (口) Sabirzyanov et al (2003), [19] (०) Koschel et al (2006 [20], (+) Dodds et al (1956) [21], (X) M. Trusler, et.al. (to be published) [22], (•) Our measurements. 


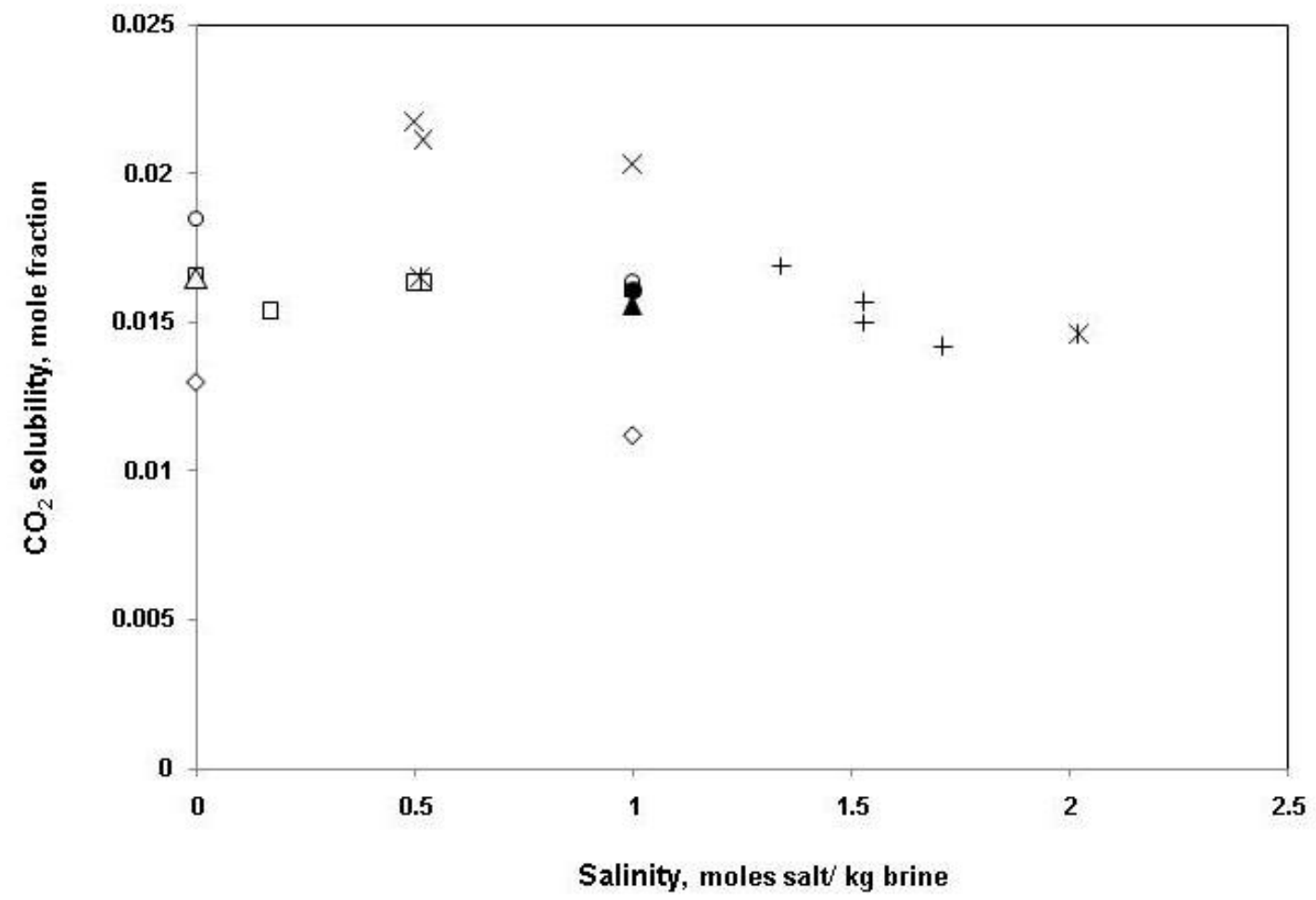

Figure 3: Solubility data for $\mathrm{CO}_{2}$ in brine versus salinity at CCS temperatures (between $33-100^{\circ} \mathrm{C}$ ) and pressures (between 8.4-10.5 MPa). Solid symbols are our measurements and open symbols are literature data $(\diamond) \mathrm{T}=$ $100^{\circ} \mathrm{C}$ and $\mathrm{p}=10.20( \pm 0.28) \mathrm{MPa}[19,20],(\square) \mathrm{T}=80.1( \pm 0.3)^{\circ} \mathrm{C}$ and $\mathrm{p}=9.51( \pm 0.57) \mathrm{MPa}[14,17],(\Delta) \mathrm{T}=70^{\circ} \mathrm{C}$ and $\mathrm{p}=9 \mathrm{MPa}\left[21,(\boldsymbol{\Delta})\right.$ our measurement], $\left({ }^{*}\right) \mathrm{T}=59.5( \pm 0.71){ }^{\circ} \mathrm{C}$ and $\mathrm{p}=10.19( \pm 0.27) \mathrm{MPa}[15,18],(\circ) \mathrm{T}=50^{\circ} \mathrm{C}$ and $\mathrm{p}=9.5( \pm 0.58) \mathrm{MPa}\left[19-21,(\bullet)\right.$ our measurement], $(+) \mathrm{T}=45^{\circ} \mathrm{C}$ and $\mathrm{p}=9.8( \pm 0.86) \mathrm{MPa}[16](\mathrm{x}) \mathrm{T}=40.3^{\circ} \mathrm{C}$ and $p=8.47( \pm 0.21) \mathrm{MPa}[17]$. 
Table 1: Solubility data for $\mathrm{CO}_{2}$ dissolved in brine measured using the isothermal de-pressurization method. The salinity was constant with 0.856 moles $\mathrm{NaCl}$ and 0.134 moles of $\mathrm{KCl}$ per kilogram water.

\begin{tabular}{|cccc|}
\hline $\begin{array}{c}\mathbf{T} \\
\left({ }^{\circ} \mathrm{C}\right)\end{array}$ & $\begin{array}{c}\mathbf{P} \\
(\mathrm{MPa})\end{array}$ & $\begin{array}{c}\text { Solubility of } \mathbf{C O}_{2} \\
\left(\mathrm{~mole} \mathrm{CO}_{2} / \mathrm{kg} \text { brine }\right)\end{array}$ & $\begin{array}{c}\text { Mole fraction of } \\
\text { dissolved } \mathbf{C O}_{2}\end{array}$ \\
\hline 70 & 9 & 0.857 & 0.0159 \\
70 & 9 & 0.836 & 0.0155 \\
70 & 9 & 0.832 & 0.0154 \\
70 & 7.58 & 0.78 & 0.0144 \\
70 & 3.44 & 0.39 & 0.0073 \\
70 & 0.34 & 0.045 & 0.0008 \\
50 & 9 & 0.886 & 0.0164 \\
33 & 9 & 1.015 & 0.0187 \\
\hline
\end{tabular}

Table 2: Solubility data of $\mathrm{CO}_{2}$ in water for different salinities and operating conditions from the literature.

\begin{tabular}{|c|c|c|c|c|c|c|}
\hline Reference & $\begin{array}{l}\mathbf{T} \\
\left({ }^{\circ} \mathrm{C}\right)\end{array}$ & $\underset{(\mathrm{MPa})}{\mathbf{P}}$ & $\begin{array}{l}\text { Salinity } \\
\text { (wt. \%) }\end{array}$ & $\begin{array}{c}\text { Salinity } \\
\text { (moles salt/ kg brine) }\end{array}$ & $\begin{array}{c}\text { Solubility of } \mathrm{CO}_{2} \\
\left(\text { mole } \mathrm{CO}_{2} / \mathrm{kg} \text { brine }\right)\end{array}$ & $\begin{array}{l}\text { Mole fraction } \\
\text { of } \mathrm{CO}_{2}\end{array}$ \\
\hline \multicolumn{7}{|c|}{ Experimental data } \\
\hline $\begin{array}{l}\text { J. A. Nighswander, } \\
\text { et.al. (1989) [14] }\end{array}$ & $\begin{array}{l}79.7 \\
80.1\end{array}$ & $\begin{array}{l}10.18 \\
9.94\end{array}$ & $\begin{array}{c}0 \\
1 \%(\mathrm{NaCl})\end{array}$ & $\begin{array}{c}0 \\
0.171(\mathrm{NaCl})\end{array}$ & $\begin{array}{l}0.9376 \\
0.8631\end{array}$ & $\begin{array}{l}0.0166 \\
0.0154\end{array}$ \\
\hline Z. Li, et.al. (2004) [15] & 59 & 10.38 & $\begin{array}{c}8.05 \% \\
\text { (Weyburn brine) }\end{array}$ & $\begin{array}{c}2.021 \\
\text { (Weyburn brine) }\end{array}$ & 0.7666 & 0.0146 \\
\hline Y. Liua, et.al.(2010) [16] & $\begin{array}{l}45 \\
45 \\
45 \\
45\end{array}$ & $\begin{array}{c}10.09 \\
10.09 \\
10.58 \\
8.59\end{array}$ & $\begin{array}{c}10 \%(\mathrm{NaCl}) \\
10 \%(\mathrm{KCl}) \\
5 \%(\mathrm{NaCl}) \& 5 \%(\mathrm{KCl}) \\
5 \%(\mathrm{NaCl}) \& 5 \%(\mathrm{KCl})\end{array}$ & $\begin{array}{c}1.71(\mathrm{NaCl}) \\
1.34(\mathrm{KCl}) \\
0.86(\mathrm{NaCl}) \& 0.67(\mathrm{KCl}) \\
0.86(\mathrm{NaCl}) \& 0.67(\mathrm{KCl})\end{array}$ & $\begin{array}{l}0.7432 \\
0.893 \\
0.825 \\
0.784\end{array}$ & $\begin{array}{l}0.0142 \\
0.0169 \\
0.0157 \\
0.0150\end{array}$ \\
\hline $\begin{array}{l}\text { J. Kiepe, et.al. (2002) } \\
\text { [17] }\end{array}$ & $\begin{array}{l}40.38 \\
80.08 \\
40.31 \\
80.08 \\
40.31 \\
80.55\end{array}$ & $\begin{array}{c}8.43 \\
9.24 \\
8.28 \\
8.74 \\
8.7 \\
9.45\end{array}$ & $\begin{array}{l}3 \%(\mathrm{NaCl}) \\
3 \%(\mathrm{NaCl}) \\
3.7 \%(\mathrm{KCl}) \\
3.7 \%(\mathrm{KCl}) \\
7.5 \%(\mathrm{KCl}) \\
7.5 \%(\mathrm{KCl})\end{array}$ & $\begin{array}{c}0.52(\mathrm{NaCl}) \\
0.52(\mathrm{NaCl}) \\
0.5(\mathrm{KCl}) \\
0.5(\mathrm{KCl}) \\
1(\mathrm{KCl}) \\
1(\mathrm{KCl})\end{array}$ & $\begin{array}{l}1.1738 \\
0.9048 \\
1.2000 \\
0.8981 \\
1.0862 \\
0.8574\end{array}$ & $\begin{array}{c}0.02112 \\
0.01636 \\
0.02174 \\
0.01636 \\
0.02031 \\
0.0161\end{array}$ \\
\hline $\begin{array}{l}\text { S. Bando, et.al. (2003) } \\
{[18]}\end{array}$ & 60 & 10 & $3 \% \quad(\mathrm{NaCl})$ & $0.514(\mathrm{NaCl})$ & 0.9127 & 0.0165 \\
\hline $\begin{array}{l}\text { R. Sabirzyanov, et.al. } \\
\text { (2003) [19] }\end{array}$ & $\begin{array}{c}50 \\
100\end{array}$ & $\begin{array}{l}10 \\
10\end{array}$ & $\begin{array}{l}0 \\
0\end{array}$ & $\begin{array}{l}0 \\
0\end{array}$ & $\begin{array}{l}1.0471 \\
0.7317\end{array}$ & $\begin{array}{c}0.0185 \\
0.013\end{array}$ \\
\hline $\begin{array}{l}\text { D. Koschel, et.al. } \\
(2006)[20]\end{array}$ & $\begin{array}{c}50.1 \\
100.1\end{array}$ & $\begin{array}{c}10 \\
10.4\end{array}$ & $\begin{array}{l}5.8 \%(\mathrm{NaCl}) \\
5.8 \%(\mathrm{NaCl})\end{array}$ & $\begin{array}{l}1(\mathrm{NaCl}) \\
1(\mathrm{NaCl})\end{array}$ & $\begin{array}{l}0.8891 \\
0.6040\end{array}$ & $\begin{array}{l}0.0164 \\
0.0112\end{array}$ \\
\hline $\begin{array}{l}\text { W. Dodds, et.al. (1956) } \\
\text { [21] }\end{array}$ & $\begin{array}{l}70 \\
50\end{array}$ & $\begin{array}{l}9 \\
9\end{array}$ & $\begin{array}{l}0 \\
0\end{array}$ & $\begin{array}{l}0 \\
0\end{array}$ & $\begin{array}{l}0.9320 \\
0.9953\end{array}$ & $\begin{array}{l}0.0165 \\
0.0176\end{array}$ \\
\hline $\begin{array}{l}\text { M. Trusler, et.al. (to be } \\
\text { published) [22] }\end{array}$ & 70.9 & 13.69 & $5 \%(\mathrm{NaCl}) \& 1 \%(\mathrm{KCl})$ & $0.86(\mathrm{NaCl}) \& 0.13(\mathrm{KCl})$ & 0.9147 & 0.0169 \\
\hline \multicolumn{7}{|c|}{ Theoretical data } \\
\hline $\begin{array}{l}\text { N. Akinfiev \& L. } \\
\text { Diamond (2010) [23] }\end{array}$ & 70 & 9 & $5.8 \%(\mathrm{NaCl})$ & 1 & 0.75 & 0.0138 \\
\hline $\begin{array}{l}\text { N. Darwish, N. Hilal } \\
(2010)[24]\end{array}$ & 50 & 9 & $5.8 \%(\mathrm{NaCl})$ & 1 & 0.9 & 0.0166 \\
\hline $\begin{array}{l}\text { N. Spycher \& K. Pruess } \\
(2010)[25]\end{array}$ & $\begin{array}{l}50 \\
90\end{array}$ & $\begin{array}{l}9 \\
9\end{array}$ & $\begin{array}{l}5.8 \%(\mathrm{NaCl}) \\
5.8 \%(\mathrm{NaCl})\end{array}$ & 1 & $\begin{array}{l}0.9 \\
0.7\end{array}$ & $\begin{array}{l}0.0166 \\
0.0129\end{array}$ \\
\hline X. Ji, et.al. (2005) [26] & $\begin{array}{l}60.15 \\
80.15\end{array}$ & $\begin{array}{l}9 \\
9\end{array}$ & $\begin{array}{ll}3 \% & (\mathrm{NaCl}) \\
3 \% & (\mathrm{NaCl})\end{array}$ & $\begin{array}{c}0.5292 \\
0.52\end{array}$ & $\begin{array}{l}0.9033 \\
0.8460\end{array}$ & $\begin{array}{l}0.0163 \\
0.0153\end{array}$ \\
\hline $\begin{array}{l}\text { N. Spycher \& K. Pruess } \\
(2005)[27]\end{array}$ & 60 & 9 & $3 \% \quad(\mathrm{NaCl})$ & 0.5 & 0.85 & 0.0154 \\
\hline $\begin{array}{l}\text { Z. Duan \& R. Sun } \\
\text { (2003) [12] }\end{array}$ & 60.15 & 10 & $5.8 \%(\mathrm{NaCl})$ & 1 & 0.8405 & 0.0155 \\
\hline
\end{tabular}

